\title{
Association Between Plasma Renin Activity with Hypertension in Children with Congenital Adrenal Hyperplasia due to 21-Hydroxylase Enzyme Deficiency
}

Siska Mayasari Lubis ( $\nabla$ siskamayasarilubis@gmail.com ) Universitas Sumatera Utara Fakultas Kedokteran https://orcid.org/0000-0002-5671-7946

Eka Lakshmi Hidayati

Universitas Indonesia Fakultas Kedokteran

Frida Soesanti

Universitas Indonesia Fakultas Kedokteran

Bambang Tridjaja AAP

Universitas Indonesia Fakultas Kedokteran

Keywords:

Posted Date: February 19th, 2021

DOI: https://doi.org/10.21203/rs.3.rs-212181/v1

License: (c) (1) This work is licensed under a Creative Commons Attribution 4.0 International License. Read Full License 


\section{Abstract}

The authors have requested that this preprint be removed from Research Square. 